\title{
FURTHER RECORDS OF SKIPPERS AND BUTTERFLIES FROM THE MILK RIVER - LOST RIVER AREA OF SOUTHEASTERN ALBERTA
}

TERRY W. THORMIN, Provincial Museum of Alberta, Edmonton; NORBERT G. KONDLA, Parks Division, Alberta Recreation and Parks, Edmonton; and CHARLES D. BIRD, Box 165, Mirror, Alberta.

Since the March 1977 article in the Blue Jay on the butterflies and skippers of this area, additional collecting by several individuals, as well as some older records just recently brought to light, have added considerably to our knowledge of the butterflies and skippers of this area. ${ }^{8}$ A recent article by Wallis and Wershler points out the unique and nationally significant conservation values present in the region. ${ }^{9}$ The in- formation presented herein adds to its already lengthy list of significant natural features.

Included here are the first published Alberta reports of the Napa Skipper (Ochlodes sylvanoides napa), Rhesus Skipper (Yvretta rhesus), Scriptura Skipper (Pyrgus scriptura), and Afranius Dusky Wing (Erynnis afranius) as well as reports of 15 other species new to this area.

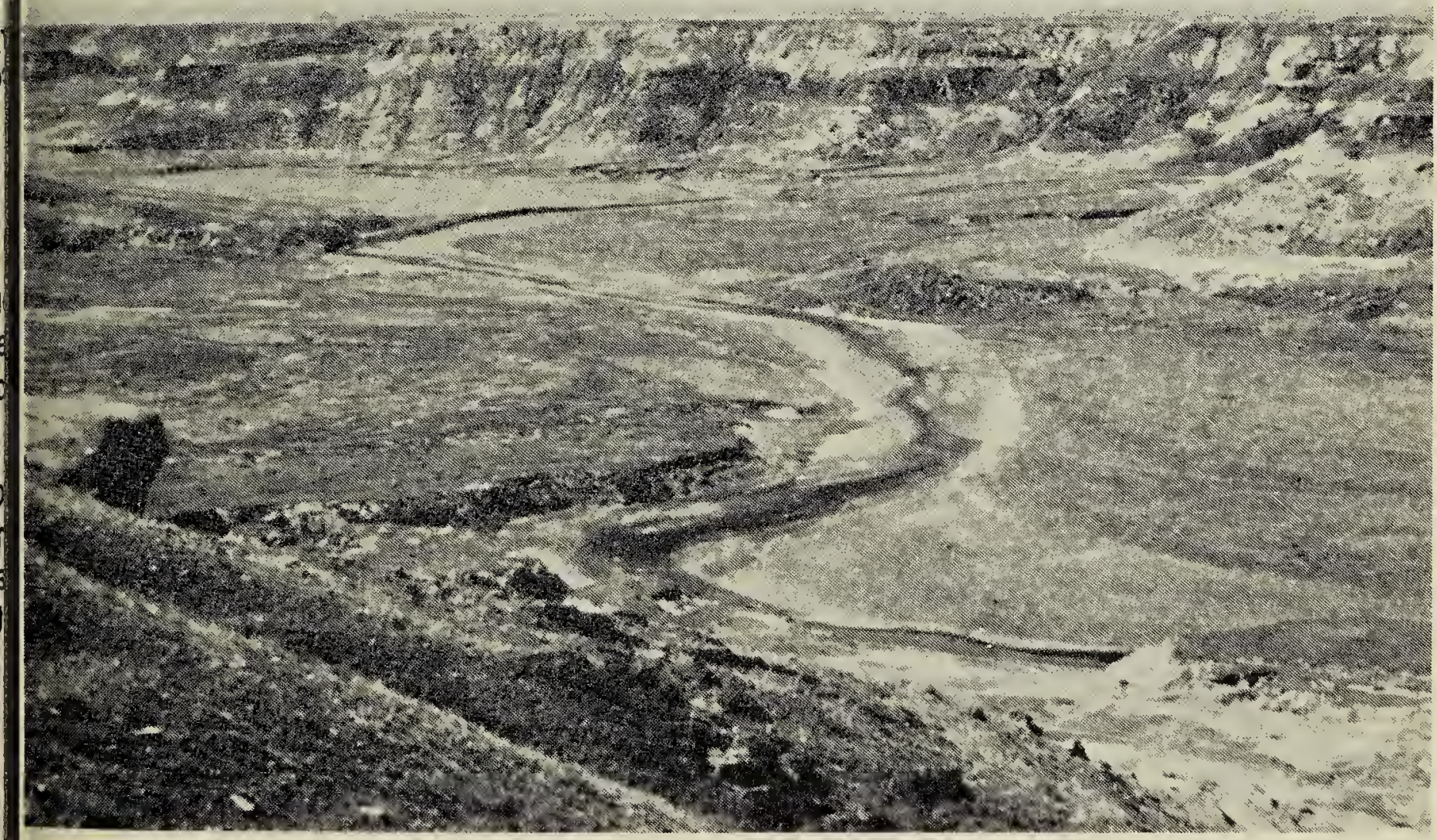

Figure 1: Lower Lost River area. In this area D. F. Hardwick found the only Canadian specimen of the Scriptura Skipper. 


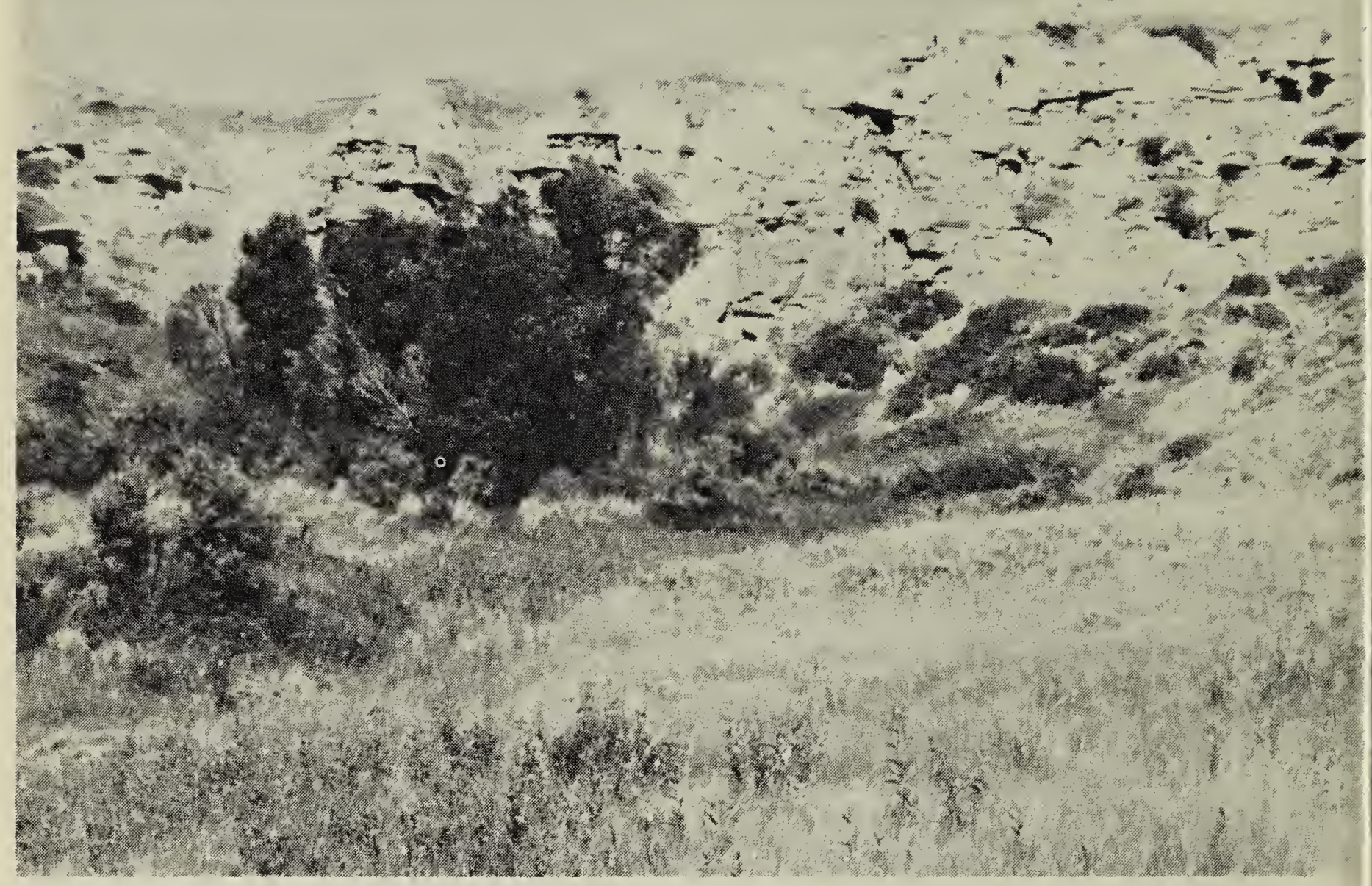

Figure 2: Wooded seepage area at base of sandstone cliff. It was here that W. W. Smith found the first Canadian individuals of Weidemeyers Admiral.

Also reported are earlier or later flight dates for 17 other species. Taxonomic changes, corrections, and notes are given for nine species. The total list of butterflies and skippers for the area is now 51 species. Undoubtedly more collecting will result in. further additions. The original paper on this area should be consulted for an environmental overview. Figures 1 to 3 illustrate some of the butterfly habitats.

\section{Specles Llst}

The scientific names and taxonomic order used in this article are taken primarily from dos Passos but incorporate more recent changes. ${ }^{1}$ Common names are taken mostly from Hooper. ${ }^{5}$ Dates listed refer to the dates species were collected and/or observed. Names given after these dates are those of the collector or observer. Where specimens were not retained by the collector specimen location is given after the collector's name. Additional information, where available, is given on relative abundance and habitat preference.

ROADSIDE SKIPPER (Amblyscirtes vialis): 22 May 1977, T. Thormin: 23 May 1977, E. Pike. Uncommon at edge of riparian forest. New record.

NAPA SKIPPER (Ochlodes sylvanoides napa): 14 and 15 August 1979, N. Kondla. Found in a variety of habitats, including riparian shrubbery, sage slope, and prairie grassland. This is the first published record for Alberta and only the second Alberta locality record of the species. Previously it was collected by G. Hilchie and by $S$. Shigematsu in the West Castle River area in the mountains of extreme southwestern Alberta. New record.

DELAWARE SKIPPER (Atrytone delaware): Alberta material of this species has in the past been referred to the sub- 




Figure 4: First Alberta specimen of the Rhesus Skipper. Upperside on left, underside on right. Wing expanse is $25 \mathrm{~mm}$.

riparian forest. The previous records of $E$. persius are actually $E$. afranius. Identification of the above mentioned specimen was confirmed by genitalic check. E. persius is single brooded, only flying in the spring. E. afranius, however, is double brooded, the second brood flying in late July and August. New flight date.

AFRANIUS DUSKY WING (Erynnis afranius): 8 June, 1978, T. Thormin; 23 and 24 May 1979, W. Nordstrom; 25 and 26 May 15 and 16 August 1979, N. Kondla. Fairly common on grassy hillsides. This is the first published report for Alberta although studies by Kondla indicate it is widespread in southern Alberta. Identity of specimens was confirmed by genitalic check. New record.

SILVER-SPOTTED SKIPPER (Epargyreus clarus clarus): 222 May 1977, T. Thormin; 16 July, 1978, N. Kondla. New flight dates.

ZELICAON SWALLOWTAIL (Papilio zelicaon nitra): The species discussed here has previously been treated as two distinct taxa, Papilio zelicaon Lucas and P. nitra W. H. Edwards. Fisher has shown that these two entities are conspecific, the black "nitra" form being a color morph of the more common yellow "gothica" form. ${ }^{4}$ Black morph 23 and 24 May 1979, N. Kondla; Yellow morph 16 July 1978 and 24 and 25 May 1979, N. Kondla; 25 May, W. Nordstrom. Locally abundant when hilltopping at escarpment edges and kame-like hills. New record.
BADLANDS OLDWORLD SWALLOWTAIL (Papilio machaon dodi): 23, 24 and 25 May 1979, N. Kondla; 8 June 1978, T. W. Thormin and A. N. Wiseley. Most abundant and easily seen on hilltops and escarpment edges. New flight dates. The taxonomy of the Papilio machaon complex in North America has been the subject of much research and controversy. Much still needs to be investigated and resolved. Emmel has assigned dodi to $P$. oregonius. ${ }^{2}$ Although the rationale for this has apparently not been published it may be a more accurate designation than assigning dodi to the single-brooded, boreal forest $P$. machaon. One specimen caught by Kondla appears to show hybrid characters between P. z. nitra and P. $m$. dodi.

WESTERN CHECKERED WHITE (Pieris occidentalis occidentalis): 23 May 1979 and 16 July 1978, N. Kondla; 2 September, 1979, T. Thormin. Common in most habitats, particularly in the fall. New record.

YELLOW ALFALFA BUTTERFLY (Colias philodice eriphyle): Taxonomic change; current taxonomic opinion now places eriphyle under philodice rather than eurytheme. 24 and 25 May 1979, W. Nordstrom; 2 September 1979, T. Thormin. New flight dates.

ALEXANDRA SULPHUR (Colias alexandra alexandra): 3 June 1956, E. E. Stearns, Canadian National Collection; 8 June 1978, T. Thormin; 15 August 1979, 
N. Kondla. Fairly common in grasslands, often seen along escarpment edges. The white morph of the female appears to be more abundant than the yellow morph. New record.

OLYMPIA MARBLE (Euchloe olympia rosa): 22 May 1977, G. Hilchie; 23 May 1977, E. Pike; 8 June 1978, T. Thormin and A. N. Wiseley; 23 and 24 May 1979, W. Nordstrom; 23 and 26 May 1979, N. Kondla. Fairly common in sageflats and grasslands, found abundantly on hilltops and escarpment edge. New record.

CORAL HAIRSTREAK (Harkenclenus titus immaculosus): 15 August 1979, N. Kondla. Shrubby seepage area. New record.

BROWN ELFIN (Callophrys augustinus): 24 May 1979, N. Kondla. Very local where the food plant, bearberry, grows. There are insufficient specimens available to assign a subspecific name. Dos Passos indicates the presence of both subspecies iroides and augustinus in Alberta. ${ }^{1}$ New record.

GRAY HAIRSTREAK (Strymon melinus): 23 to 25 May 1979 and 16 August 1979, N. Kondla; 23 and 25 May 1979, W. Nordstrom. Taxonomic note: The series collected by Kondla appears to show consistent differences from the eastern melinus humuli, melinus setonia from British Columbia, and melinus franki from Arizona. Therefore no subspecies name is assigned. This species was observed to be fond of hilltopping where large brown sandstone rocks were present. When a brown van was parked at the escarpment edge, it soon attracted hilltopping hairstreaks that treated the van as a large rock. New flight dates.

PURPLISH COPPER (Epidemia helloides): Taxonomic change; nomenclature follows Ferris. ${ }^{3} 16$ August 1979 , N. Kondla. New flight date.

MELISSA BLUE (Lycaeides melissa melissa): 15 and 17 August 1979, N. Kondla. Most abundant in badlands and sage flats. New flight dates.

GREENISH BLUE (Plebejus saepiolus amica): 22 May 1977, T. Thormin. New flight date.

SHASTA BLUE (Plebejus shasta minnehaha): 3 July $1973, \mathrm{G}$. Hilchie. Ap- parently a scarce to uncommon species in the badlands. New record.

SILVERY BLUE (Glaucopsyche lygdamus couperi): 23 May 1979, W. Nordstrom; 24 May 1979, N. Kondla. New flight date.

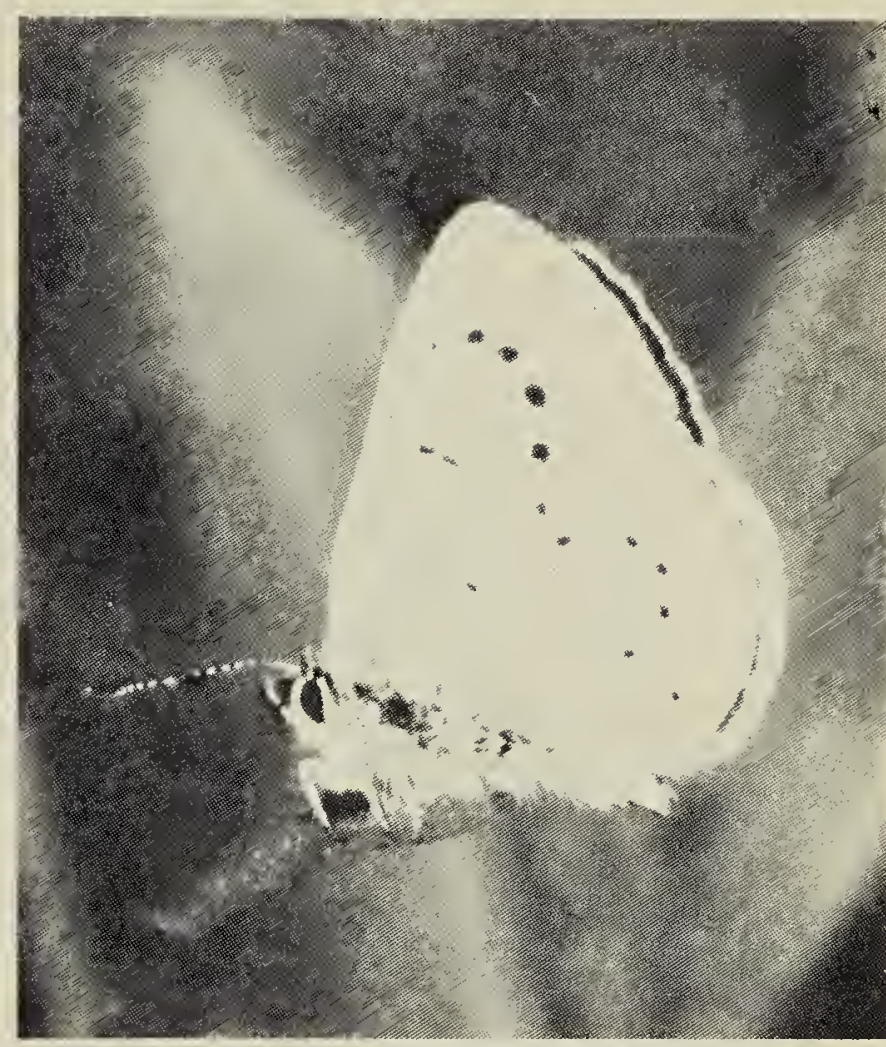

Silvery Blue.

T. W. Thormin

SPRING AZURE (Celastrina argiolus lucia): 23 May 1979, W. Nordstrom; 23 and 26 May 1979, N. Kondla. Found in coulee aspen stands and riparian cottonwoods where red osier dogwood grows. New flight dates.

WEIDEMEYER'S ADMIRAL (Limenitis weidemeyeri oberfoellii): 16 July 1978, N. Kondla. Observations by $\mathrm{C}$. Wallis indicate that this species has a shorter flight period than the related White Admiral. New flight date.

PAINTED LADY (Cynthia cardui): 22 May 1977, T. Thormin, 23 and 26 May 1979 and 15 August 1979, N. Kondla, 2 September 1979, T. Thormin. Fairly common where hilltopping. This species apparently does not overwinter. In late May individuals often move into the province from further south, usually in a somewhat worn condition, to lay their eggs. It is from these that the fall brood hatches. New record.

MILBERT'S TORTOISE SHELL (Nymphalis milberti furcillata): 16 July 
1978, N. Kondla. 15 August 1951, D. F. Hardwick, Canadian National Collection. Apparently uncommon. New record.

ACASTA CHECKERSPOT (Chlosyne acastus acastus): 22 May 1977, T. Thormin, 26 May 1979, N. Kondla. Observations by Kondla at Drumheller and at Dinosaur Park show a small second brood in August. August records are also expected for the Milk River area. New flight dates.

PEARL CRESCENT (Phyciodes tharos): 22 May 1979, T. Thormin; 26 May 1979, 14 to 17 August 1979, N. Kondla. Originally reported as subspecies pulchella, variation at the subspecies level in southern Saskatchewan, southern Alberta, and northern Montana needs further research. New flight dates.

APHRODITE (Speyeria aphrodite): The previous article reported this as subspecies mayae (properly called manitoba). Examination of the literature and comparison of specimens shows that specimens from this area appear intermediate between manitoba and ethne. For this reason no subspecific name is applied. Kondla has commented on the apparent affinities of $S$. aphrodite in Alberta. ${ }^{6}$ More research is certainly needed. 16 July 1978, 15 and 16 August 1979, N. Kondla. New flight dates.

VARIEGATED FRITILLARY (Euptoieta claudia): 14 August 1979, N. Kondla. Uncommon in grasslands. This species does not overwinter in Alberta, but moves into the province each summer. New record.

RINGLET (Coenonympha inornata benjamini): 22 May 1977, T. Thormin. New flight date.

RIDING'S SATYR (Neominois ridingsii ridingsii): 16 July 1979, N. Kondla. Found on upper escarpments and adjacent grassland where bare soil is available. New flight date.

COMMON WOOD NYMPH (Cercyonis pegala ino): 14 August 1979, N. Kondla. New flight date.

ALBERTA ARCTIC (Oeneis alberta alberta): 23 and 25 May 1979, W. Nordstrom; 23 and 26 May 1979, N. Kondla. Abundant in prairie grasslands. New record.

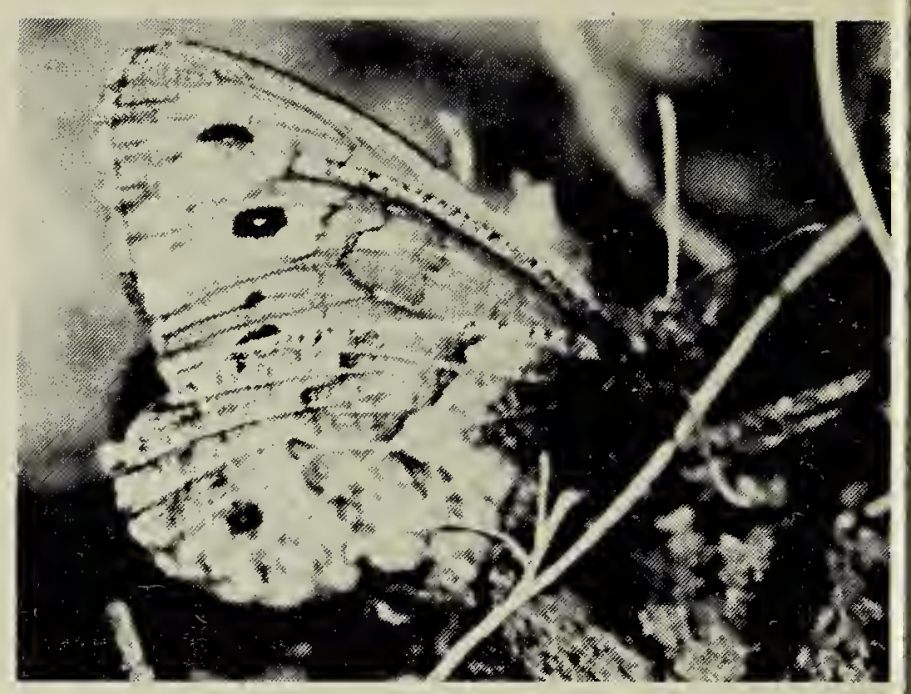

Alberta Arctic.

T. W. Thormin

'DOS PASSOS, C. F. 1964. A Synonomic List of the Nearctic Rhopalocera. The Lepidopterist's Society, Memoir No. 1. $145 \mathrm{pp}$.

${ }^{2} E M M E L$, J. F. 1975. Subfamily Papilioninae. pp. 390-402. In Howe, W. H. The Butterflies of North America. Doubleday and Co. Inc., New York. 633 pp.

${ }^{3}$ FERRIS, C. D. 1977. Taxonomic revision of the species dorcas Kirby and helloides Boisduval in the genus Epidemia Scudder (Lycaenidae; Lycaeninae). Bull. of the Allyn Museum 45:1-42.

${ }^{4}$ FISHER, M. S. 1977 . The taxonomy and identity of Papilio nitra W. $\mathrm{H}$. Edwards in Colorado (Papilionidae). Bull. of the Allyn Museum 47:1-8.

${ }^{5}$ HOOPER, R. R. 1973. Butterflies of Saskatchewan. Saskatchewan Dept. Renewable Resources. 216 pp.

${ }^{6}$ KONDLA, N. G. 1979. Skippers and butterflies of a prairie farm. Alberta Natural. 9:71-75.

${ }^{7} \mathrm{McCABE}, \mathrm{T} . \mathrm{L}$. and R. L. POST. 1977. Skippers (Hesperioidea) of North Dakota. North Dakota Insects Publication No. 11. North Dakota State Univ. $69 \mathrm{pp}$.

${ }^{8}$ SMITH, W. W. and C. D. BIRD. 1977. Some butterflies and skippers from the Milk River-Lost River area of Southeastern Alberta. Blue Jay 35: 15-18.

'WALLIS, C. and C. WERSHLER. 1979. Milk River Canyon. Nature Canada 8:36-45. 